\title{
BALL (Blogs Assisted Language Learning): Are Malaysian Secondary School Students Prepared to Use Blogs in ESL Learning?
}

\author{
Zurainee Ariffin \\ Awang Had Salleh School, UUM \\ E-mail: aneem1515@yahoo.com \\ Aizan Yaacob \\ Universiti Utara Malaysia \\ E-mail:aizan904@uum.edu.my
}

Doi:10.7575/aiac.alls.v.5n.5p.123

Received: 13/07/2014

URL: http://dx.doi.org/10.7575/aiac.alls.v.5n.5p.123

Accepted: 01/08/2014

\begin{abstract}
This study aimed to find out second language learners' perceptions on the use of blogs in their learning process. Participants were 20 secondary school students from a suburban school in Kelantan, Malaysia. The students read articles, discussed in their respective groups and posted their comments in their group blogs in two kinds of learning environment; being supervised face-to-face and virtually. A survey and also oral interview were administered to elicit participants' perceptions on the use of blogs. The results showed that although the incorporation of blogs in ESL learning were perceived positively among the learners, teachers need to be aware of several factors affect the effectiveness of using this technology in their teaching such as students' gender, personality and learning preferences. This paper also provides some pedagogical implications in the use of blogs for ESL learning.
\end{abstract}

Keywords: Classroom blogging, Blog-assisted language learning, ESL reading and writing

\section{Introduction}

The advancement of Internet and Web 2.0 technologies provide students with more choices and flexible learning alternatives. The potential benefits of the Internet and Web 2.0 technologies can assist students' learning. Hurlburt (2008) suggests that educators should take advantage of the technology in education specifically, "Internet and Web 2.0 technologies afford students opportunities to seek information, collect their own material, communicate, make meaning, and evaluate end products" (Nelson, Christopher, \& Mims, 2009, p. 81).

Blogs are one of the most popular Web 2.0 tools. From a simple online personal diaries, blogs have evolved to be communication tools that enable people to be engaged to collaborate (Scheidt, 2009; Alexander, 2006), share knowledge (Pinkman, 2005), peer review (Yang \& Chang, 2012; Williams and Jacobs, 2004) as well as to reflect (Yang, 2009; Xie, Ke, \& Sharma, 2007; Good \& Whang, 2002). Blogs can provide ongoing feedback and assist teachers in designing learning activities.

\subsection{Blogging in Education}

Educators started to find ways to integrate computer-mediated communication tools in their teaching and learning since blogs have gained popularity among young generation. Blogging is considered as one of the most popular online activities among social-media. Prior study has shown that these technologies offer promising benefits for instructors and students (Williams \& Jacobs, 2004). Blogging enables students to think when they write the entries or posts and receive feedback from larger audience, instead of merely from their teacher. Blog archives provide teachers with the information about the students' learning and become the source of reference about their learning. In addition the archives can be used as a basis for ongoing feedback from the readers which includes teachers and the other students. The information available can guide teachers to redesign their learning activities to fulfill the learning objectives. Studies on the use of blogs show that this technology can enhance reflective thinking (Farmer, Yue, \& Brooks, 2008), deeper learning and knowledge construction (Ferdig \& Trammel, 2004; Williams \& Jacobs, 2004).

In addition, the use of blogs also builds a sense of community (Halic, Lee, Paulus and Spence, 2010). Another study carried out by Ellison and Wu (2008) examined students' perception on the use of blogs in their learning process and its effect on comprehension. Most of the respondents indicated positive attitudes towards the inculcation of blogs in their learning process. They stated that reading the entries from their friends' blogs helped them to understand the course better. 
Various studies have carried out to find out learners' attitudes toward the use of blogs in higher education (Ellison \& Wu, 2008; Halic, Lee, Paulus \& Spence, 2010; William \& Jacobs, 2004). Yang (2009) found that Taiwanese English as Foreign Language (EFL) teachers appreciated the use of blogs for promoting critical thinking skills, reporting that the use of blogs for discussion was more effective than face-to-face discussion. Coutinho (2007) and Zeng and Harris (2005) obtained similar results. However, Xie, Ke and Sharma (2007) argued that interactivity could have a negative effect on critical thinking. The researchers carried out the study to investigate the effect of peer feedback on college students' reflective thinking skills and the findings showed that peer feedback had negative effects on students' reflective thinking skills. The researchers concluded that this happened because of the negative comments given by peers.

Generally, the findings from the previous studies show that students have positive attitudes towards the inculcation of blogs in their teaching and learning process. The findings also indicate that blogs can enhance reflective thinking, provide deeper learning and construct the knowledge. The aim of this study is to extend the effort to find out the students' perception towards the use of blogs in their language teaching and learning process specifically in their reading program and also to analyze the interactional patterns exist in the students' blogs when they were supervised face-to-face and virtually.

\section{Statement of Problem}

Many of the students do not read the English materials and books provided by the school to help enhancing their proficiency of the target language. Next, they lack in-class resources to support authentic learning except for the provided textbook. In addition, the students have little experience integrating technology in their teaching and learning process. Finally, the students depend on English lessons to use, to get the input and to explore the language. Teachers who use online instruction often claimed this kind of instruction gives the opportunities for students who might feel shy to use the language in a face-to-face teaching and learning instruction to participate in a classroom community.

However, there are scholars think that students who feel self-conscious about their writing will either limit their participation or stop it completely (Yena \& Waggoner, 2003). Thus, the students might still not participate in online discussion. Those who implement the hybrid approach of face-to-face and online instruction believe that the combination of both provides opportunities for students to be involved in both mediums or at least choose one of mediums that suits them to be able to involve in the use of the targetted language (Aycock, Garnham, \& Kaleta, 2002; Stine, 2004). Studies found out that students seem to have positive acceptence and attitudes toward BALL (Arani, 2005; Pinkman, 2005; Cheng, 2006; Sun, 2010), but the students do not have the desire to engage in blog-assisted writing activities on their own willingly when the programme implemented with them ended (Chiao, 2006; Wu, 2008; Lin, Lin, \& Hsu, 2011).

The conclusion is that the students like BALL but they need to be urged and monitored by teachers in doing so(Wu, 2008; Miyazoe \& Anderson, 2010). It is clear that the students in these studies did not contribute to the posts and comments in their group blogs once the research projects motivating them had finished. Questions arise, does the presence of the teacher has any effect on the students' posts and comments? Do the interactional patterns differ when the students post in two different setting? What are the factors that contribute to their nature of blog posts? Are the students ready to collaborate in the targetted language by using blogs as a platform for their group discussion?

For this purpose, research questions that need to be answered are as follows:

RQ1 What are the students' perceptions about the use of blogs to collaborate for their language learning?

RQ2 Does the presence of teacher give any influence on students' participation in blog discussion?

This study will integrate the use of blogs in their learning process to help the students to face real world challenges and to encourage them to read English materials by using blogs as a platform to use language beyond English lessons.

\section{Methodology}

\subsection{Research Setting and Participants}

The study was conducted in a secondary school in Kota Bharu, Kelantan. Twenty students of form four agreed to join in the programme. 4 Alpha was the first science class in this school. Although it was the first class, the students had mixed abilities including their language proficiencies. They formed their own group and from the formation, there were 3 girls' groups and 2 boys' groups. The groups were named as follow:

Table 1. Students' Profile

\begin{tabular}{ccccc}
\hline $\begin{array}{c}\text { ALPHA 1 } \\
(\text { GIRLS })\end{array}$ & $\begin{array}{c}\text { ALPHA 2 } \\
\text { (BOYS) }\end{array}$ & $\begin{array}{c}\text { ALPHA 3 } \\
\text { (GIRLS) }\end{array}$ & $\begin{array}{c}\text { ALPHA 4 } \\
\text { (GIRLS) }\end{array}$ & $\begin{array}{c}\text { ALPHA 5 } \\
\text { (BOYS) }\end{array}$ \\
\hline & & & & \\
$\mathbf{1 A 1}$ & $2 \mathrm{~A} 1$ & $3 \mathrm{~A} 1$ & $4 \mathrm{~A} 1$ & $5 \mathrm{~A} 1$ \\
$\mathbf{1 A 2}$ & $2 \mathrm{~A} 2$ & $3 \mathrm{~A} 2$ & $4 \mathrm{~A} 2$ & $5 \mathrm{~A} 2$ \\
$\mathbf{1 A 3}$ & $2 \mathrm{~A} 3$ & $3 \mathrm{~A} 3$ & $4 \mathrm{~A} 3$ & $5 \mathrm{~A} 3$ \\
$\mathbf{1 A 4}$ & $2 \mathrm{~A} 4$ & $3 \mathrm{~A} 4$ & $4 \mathrm{~A} 4$ & $5 \mathrm{~A} 4$ \\
& & & & $\mathrm{~N}=4$ \\
$\mathbf{N = 4}$ & $\mathrm{N}=4$ & $\mathrm{~N}=4$ & & $\mathrm{~N}=4$ \\
\hline
\end{tabular}


The class met once a week for a two-hour session in the school computer lab. Since the aim of the research was to probe students' learning experiences with BALL, the programme was implemented in three months. The duration provided ample time for students to really experience the use of blogs in their learning process. The students were monitored both during face-to-face sessions and also virtually when they blogged outside the class lessons. Students were required to post at least one article the group dealt with in a week.

\subsection{Research Design}

The classes were carried out in a computer laboratory and each student was provided with a computer that had the Internet connection to facilitate in-class blogging activities. All students have at least a personal computer, a laptop or a smart phone, so after-class blogging activities were feasible. The students were divided in groups of four and they chose their own group members. Then, they created their own group blog by using blogspot.com and all members of the group have the username and the password of their own respective blogs. The teacher joined the blog group discussions by becoming the follower. The blogs were owned and maintained by their group members. There were 5 blogs which were named as Alpha 1, Alpha 2, Alpha 3, Alpha 4 and Alpha 5.

In every in-class meeting, the students will choose a reading material from the class library and discuss in their respective groups about the main ideas, characters, moral values and the issues raised in the materials and relate them to their own personal lives. Then, they posted their entries in their group blogs and all group members would comment on their friends' entries. For virtual supervision, the students work from their own places. They searched for their own reading materials and shared them with their group members. Teacher monitored the students' progress virtually. The students were required to post their comments about the articles they dealt with weekly and provided comments and feedback to their friends' entries.

\subsection{Data collection}

Research question one is about students' perceptions about the use of blogs in their language learning process. A survey questions were distributed at the beginning of the study to ascertain information on their technology ability, interest in reading L2 materials and English proficiencies.

Then, interviews were conducted twice; before the study and after the study. The interviews took place at the same location (the teacher's room), and the students were interviewed in their own groups. The interview duration for each group was about 15 minutes. To facilitate the collection of data, a set of open-ended questions corresponding to the research questions was used. This helped to justify and validate their responses in relation to their experience and perceptions of using blogs. Since the students' English proficiency levels especially in speaking were elementary to intermediate, all interviews were conducted in Malay language, their mother tongue and for the written responses they were allowed to use their first language to write out their responses. This enabled the students to express themselves clearly, precisely and explicitly (Lin, M. H., Groom, N., \& Lin, C.-Y., 2013) However, the interview extracts in this paper were translated into English. The findings from the data sources will be discussed in the analysis result.

To answer research question 2 which is to investigate whether or not the presence of teacher gives any influence on students' participation in blog discussion, the number of students' blog entries were calculated for the total posts and the entries were analyzed by using Fleming Online Analysis (Fleming, 2008). The analysis covered five aspects; Promptness and Initiatives, Delivery of Posts' Relevance of the Posts, Expression within the Posts and Contribution to the Learning Community. Each aspect is given the band as:

\begin{tabular}{|c|c|}
\hline Band & Mark \\
\hline Below Average & 1 \\
\hline Average & 2 \\
\hline Good & 3 \\
\hline Excellent & 4 \\
\hline
\end{tabular}

The students' individual posts were analyzed and placed in the best-fit band and the average of the students' performance and the posts for each group were calculated. Then the criterion for each aspect of the posts was compared between the face-to-face and virtual supervision.

\subsection{Data Analysis}

The survey questions to elicit ascertain information on the students' technology ability and prior knowledge of blogs, interest in reading L2 materials and English proficiencies were dealt with quantitatively by looking at the percentages of the students' responses for each question. Two open-ended questions helped to understand their answers in depth.

In order to answer research question on the students' perceptions about the use of blogs to collaborate for their language learning, the students' interview transcripts were coded to find the emerging themes. The data gathered from group Alpha 1was analyzed by two coders independently. The first coder was the researcher herself and the second coder was an experienced English teacher who has been teaching English for 14 years and also has a master degree in teaching English as a second language. The coders then compared the codes applied to the scripts and discussed the coding results. The obvious different coding was discussed and the coders came to an agreement on the use of the most suitable codes for the responses. After that, they continued coding the findings from the other four groups independently. After all data was coded, the two coders again compared the result gained and reconciled the 
differences. The written responses given for the open-ended survey were analyzed for themes of students' general experience with this blogging activity, their perception on how blogs can help to improve their second language learning and the problems encountered during the programme. The survey was also to triangulate the data gathered from the interview.

The students' blogs were printed out and counted manually for the total of posts for entries and comments for each supervision; face-to-face and virtually and the writing was analyzed by using Fleming's online assessment tool. The two researchers analyzed the blog entries by reading each blog entries and comments. The students were evaluated individually according to the posts and comments and the average mark for each criterion was calculated. After that, the average mark for all the group members for each group was gathered. After each group had their average mark for each criteria examined, the findings were compared between the average gained for face-to-face supervision and the virtual supervision to find out whether or not the presence of teacher gives any influence on students' participation in blog discussion. The data was presented in the form of a table.

\subsection{Results}

\subsubsection{Survey}

The researcher distributed to the entire class consisted of 20 students a survey questions at the beginning of the study to ascertain information on their technology ability and prior knowledge of blogs, interest in reading L2 materials and English proficiencies.

\section{$\underline{\text { Technology ability }}$}

The response for their background in blogging showed that 16 out of 20 students (80\%) felt that they had some experience with blogging and 4 others (20\%) claimed to have the basic knowledge about blogs. They reported that they read blogs that are related to their interests such as entertainment, and sports. Four out of twenty students had their own blogs before joining the programme. They also frequently used internet connection in their daily lives whether by using computer, laptops or mobile phones. 17 out of $20(85 \%)$ stated that they were online on daily basis and they used social media such as Instagram, Facebook and Twitter. The other $3(15 \%)$ students stated that they were controlled by their parents and they got the access to internet only at school when they entered computer lab and also during weekends.

\section{Interest in Reading L2 Materials}

Only 3 out of 20 students (15\%) admitted that they had interest in reading L2 and they read English materials whenever they had accessed to them. Still, they preferred reading L1 materials. The others (85\%) read English materials when assigned by the teacher, normally in their reading lessons in which they would read the texts and answer comprehension questions as well as to write out the summary of the passage. They were more on the intensive reading, instead of extensive reading.

\section{English Proficiencies}

The students' language proficiencies were measured by using their PMR result. 8 out of 20 students (40\%) scored A(excellent) for their PMR (the public examination); 3 (15\%) scored B (good) and the others (45\%) scored C (Intermediate). This indicated that this class has mix abilities students for language competencies.

\subsubsection{Interview and Open-ended Survey Questions}

Questions were asked to the students to elicit their responses towards the use of blogs in their language learning.

i. $\quad$ Do you like to use blogs to share about your reading experience with your group members?

16 out of $20(80 \%)$ of the students gave a positive response to this question. They stated that blogs act as platform for them to share their reading experience, help them to use more L2 outside the English lessons. The responses given by students were such as:

\begin{tabular}{|l|l|}
\hline 1A1 & "Yes, we have a place to share and we have the power to control the place" \\
\hline 3A3 & $\begin{array}{l}\text { "Yes, I learn a lot and now I notice, we use more English and it is fun to write } \\
\text { and not be graded." }\end{array}$ \\
\hline 4A2 & $\begin{array}{l}\text { "I like, I can read a lot of English texts after this and I can search for my own } \\
\text { texts and share with my friends." }\end{array}$ \\
\hline 5A4 & $\begin{array}{l}\text { Yes and I like because I can always get the reading texts from the other group } \\
\text { blogs, easy to copy and paste." }\end{array}$ \\
\hline
\end{tabular}

The responses indicated that the students felt that blogs served as a platform for them to share their reading materials and experience. Blogs also gave them more authority to control the discussion space and choose the reading materials that cater to their own interest. Still, there are remarks given by some students that teachers need to take into consideration if they choose to use blogs as their teaching aid such as:

\begin{tabular}{|l|l|}
\hline 1A3 & $\begin{array}{l}\text { "I like to use blogs although sometimes I feel a bit busy with my homework } \\
\text { and other things. My group members keep telling me to read and to post in } \\
\text { our blogs." }\end{array}$ \\
\hline "Ah2 & $\begin{array}{l}\text { "This is great, but honestly, quite hard for me to find the time at home to blog } \\
\text { because of the homework." }\end{array}$ \\
\hline 3A4 & "Okay, but I really need to find time." \\
\hline
\end{tabular}




\begin{tabular}{|l|l|}
\hline $4 \mathrm{~A} 3$ & "Yes, but only with my group members, not really like to share with others." \\
\hline $5 \mathrm{~A} 2$ & $\begin{array}{l}\text { "Okay, the idea of sharing is good but I need to find time to write the } \\
\text { sentences and edit before I post. The idea that other students from other } \\
\text { classes reading our blog, that is the one I don't like" }\end{array}$ \\
\hline
\end{tabular}

The responses showed that even though the students like the implementation of BALL they felt time was their main constraint to participate actively since they were tied up with a lot of other commitments such as homework. Some of them also needed to spare some time to edit their entries before posting in blogs to make sure their thoughts were put into the correct sentences. In addition, the students also felt uncomfortable to know that blogs can be accessed by other students, not only their classmates.

ii. Do blogs help you to improve your language competencies?

All the students agreed that blogs did help them to improve in their second language because blogs provided them a place where everybody was using English. During face-to-face in class discussion, normally the same students would participate in discussions, leaving the quiet ones behind. During in-class discussion, most of them were using their mother tongue because they were afraid that their friends "might laugh at $m y$ (their) wrong pronunciation" (5A1). They also felt "not confident" (1A2) and "shy" (2A3) to use L2. When they had to use English in their blogs, the responses recorded were such as:

\begin{tabular}{|l|l|}
\hline 1A1 & $\begin{array}{l}\text { "Yes, it is a place for us to use English fully. Nobody is focusing on our } \\
\text { grammar because we focus more on discussion." }\end{array}$ \\
\hline 1A4 & $\begin{array}{l}\text { "Blogs help us a lot. We have more chance to use English. Now, we are } \\
\text { using more and more English." }\end{array}$ \\
\hline 2A3 & $\begin{array}{l}\text { "We have our own place to share our thoughts. I know the others are reading } \\
\text { our blogs but what matters to me, my group members." }\end{array}$ \\
\hline 3A2 & $\begin{array}{l}\text { "We are learning outside the class and my friends help me a lot. I can always } \\
\text { ask my friends to edit what I want to write. I learn a lot from them." }\end{array}$ \\
\hline 4A3 & $\begin{array}{l}\text { "I would say yes because we have to search for the materials on our own and } \\
\text { we need to understand the materials before we share with our friend." }\end{array}$ \\
\hline 5A4 & "I like because not only teacher, but my friends are using English in our blog." \\
\hline
\end{tabular}

iii. What are the problems you faced when BALL programme was implemented?

For the final part of the writing assignment, the students highlighted the problems they faced during the reading and reading activities. The most common problems faced by the students were:

- low internet connection especially when the lessons were in the morning.

- group members who refused to participate actively in blogging process

- group members didn't give immediate feedback after the posts.

- the in-class discussion among the group members about L2 articles were mostly conducted in their mother tongue (Kelantanese dialect)

- some group members loved asking about the meaning of certain words in the articles, instead of discussing the main issues raised.

- some group members loved criticizing their friends' posts by highlighting the use of ungrammatical sentences or wrong word choice.

\subsubsection{Blog Posts}

\section{Total Number of Posts}

The number of blog posts showed the students' participation throughout the programme. It is important to indicate their commitment in the use of online learning in their teaching and learning sessions. Their participation in the blogs also reflected their perception about the use of blogs.

Table 2. The Blog Posts by Groups

\begin{tabular}{cccc}
\hline GROUP: & FACE-TO-FACE & VIRTUAL & TOTAL \\
ALPHA & & & \\
\hline 1 & 65 & 67 & 132 \\
2 & 47 & 30 & 77 \\
3 & 35 & 44 & 79 \\
4 & 53 & 88 & 141 \\
5 & 35 & 43 & 78 \\
TOTAL & 235 & 272 & 507 \\
\hline
\end{tabular}




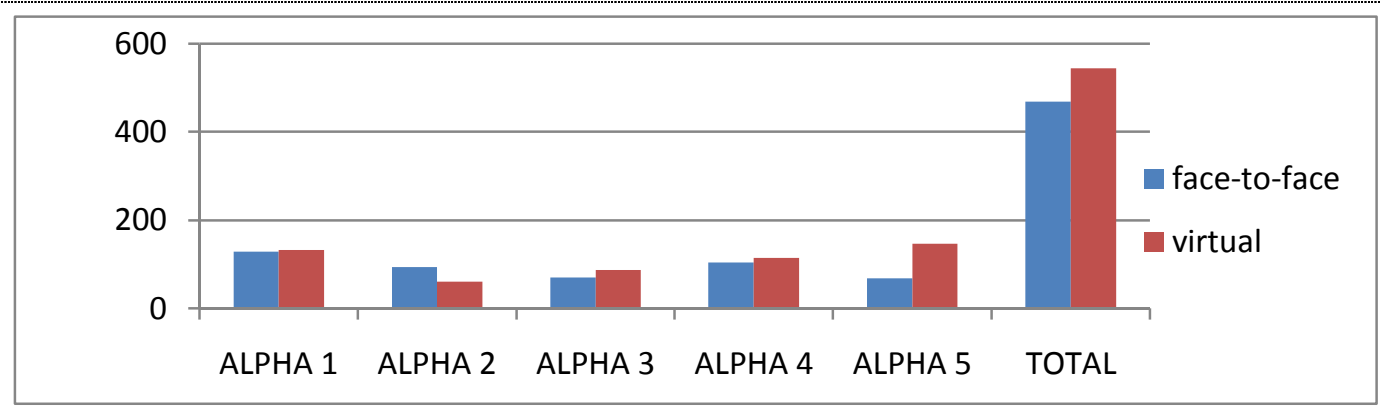

Figure 1. The Blog Posts by Groups

The graph shows that 4 groups adhered to the trend shown by the total number of blog posts for both supervisions. Generally, Alpha 1,3, 4 and 5 indicated that they posted more during virtual supervision compared to the face-to-face supervision. During the interview, when asked about the obvious trend, their response were,

\begin{tabular}{|c|l|}
\hline $5 \mathrm{~A} 1$ & $\begin{array}{l}\text { Feel more comfortable, you are not looking at us(giggle). More relax, } \\
\text { teacher. I draft, I edit and I read again, then only I post (pause) more } \\
\text { confident. }\end{array}$ \\
\hline 4A2 & $\begin{array}{l}\text { Freedom...yes...freedom to choose our reading texts. We get many } \\
\text { interesting texts and we share. In our class library very limited....the texts. }\end{array}$ \\
\hline 3A4 & $\begin{array}{l}\text { Use more time to blog, at school, rushing. We need to read, discuss and } \\
\text { then blog...don't want to write silly things in blog, at home I have time. }\end{array}$ \\
\hline
\end{tabular}

Their responses indicated that the students felt more secured when they were not being monitored by the teacher when they posted in their blogs. Plus, they had more time to choose the interesting reading materials, to think of what to post and comment and also they feel more comfortable being at their own places. However, Alpha 2 did not follow the pattern. The number of posts during face-to-face supervision was more compared to during virtual supervision. When they were asked about this, these were their responses.

\begin{tabular}{|l|l|}
\hline A2A & You are there, teacher, you are monitoring us. \\
\hline A2B & We are aware, teacher, you always come to our group. \\
\hline A2C & Easy connection, easier for us because we help each other. \\
\hline A2D & $\begin{array}{l}\text { We check our sentences together before we post. We correct our } \\
\text { sentences first. A lot of homework, teacher, cannot do at home }\end{array}$ \\
\hline
\end{tabular}

This particular group provided the reasons for them to post more during face-to-face supervision which including their awareness of the presence of teacher to monitor their progress, the facilities available at school, to be able to do peerconsultation and to finish the workload they faced at home.

Fleming's Online Assessment Tool

The nature of students' blog posts were analyzed by using Fleming's Online Assessment Tool (2008). The students' posts were analyzed based on 5 categories; Promptness and Initiatives, Delivery of Posts, Relevance of Posts, Expression within the Posts and Contribution to the Learning Community.

The general analysis of all the five group blogs shows the following,

\begin{tabular}{|c|l|l|}
\hline CATEGORY & $\begin{array}{c}\text { FACE-TO-FACE SUPERVISION } \\
\text { (in computer lab) }\end{array}$ & \multicolumn{1}{|c|}{$\begin{array}{c}\text { VIRTUAL SUPERVISION } \\
\text { (at the students' own place) }\end{array}$} \\
\hline $\begin{array}{c}\text { Promptness and } \\
\text { Initiatives }\end{array}$ & $\begin{array}{l}\text { Consistently responds to postings } \\
\text { in less than 24 hours, demonstrates } \\
\text { good self-initiative }\end{array}$ & $\begin{array}{l}\text { Consistently responds to postings } \\
\text { in less than 24 hours, demonstrates } \\
\text { good self-initiative }\end{array}$ \\
$\begin{array}{l}64 \text { from } 71 \text { posts were responded in } \\
\text { less than } 24 \text { hours and the discussion } \\
\text { among the group members mostly } \\
\text { take } 2 \text { to } 5 \text { minutes to be responded } \\
\text { by other group members. }\end{array}$ & $\begin{array}{l}97 \text { out of } 105 \text { posts were responded } \\
\text { in less than } 24 \text { hours. }\end{array}$ \\
$\begin{array}{l}\text { This situation is excluded for Alpha 2 } 2 \\
\text { and alpha 5. Although the members } \\
\text { did respond within 24 hours but they } \\
\text { needed to be prompted by the } \\
\text { teacher. }\end{array}$ & $\begin{array}{l}\text { Ine condition included all the groups. } \\
\text { Virtual supervision in which they had } \\
147 \text { posts out of } 544 .\end{array}$ \\
\hline
\end{tabular}




\begin{tabular}{|c|c|c|c|}
\hline & Delivery of Posts & $\begin{array}{l}\text { Consistently uses grammatically } \\
\text { correct posts with rare misspellings } \\
\text { Among the errors made by the } \\
\text { students were: } \\
\text { 1. the use of sentence connectors: eg, } \\
\text { Although he is handsome, but his } \\
\text { attitude is so arrogant.(A2A) } \\
\text { 2. Subject Verb Agreement } \\
\text { I really love how the story start and } \\
\text { how the story end. (A5B) } \\
\text { 3. Most of the words were spelt } \\
\text { accurately. }\end{array}$ & $\begin{array}{l}\text { Consistently uses grammatically } \\
\text { correct posts with rare misspellings } \\
\text { (the similar grammar errors like } \\
\text { during face-to-face supervision) }\end{array}$ \\
\hline & Relevance of Posts & $\begin{array}{l}\begin{array}{l}\text { Frequently posts topics that are } \\
\text { related to discussion content } \\
\text { prompts further discussion of } \\
\text { topic. }\end{array} \\
\text { The students ended their posts or } \\
\text { comments with questions such as: } \\
\text { "Why do you choose this article?" } \\
\text { (A5A)/ Why must our parents know } \\
\text { what we do? (A2C) } \\
\text { They also kept referring to the text } \\
\text { read: } \\
\text { "Guys, if you really read this article, } \\
\text { you'll realize that parents do not } \\
\text { intent to hurt us..." (A5C) }\end{array}$ & $\begin{array}{l}\begin{array}{l}\text { Frequently posts topics that are } \\
\text { related to discussion content } \\
\text { prompts further discussion of } \\
\text { topic. }\end{array} \\
\text { Still, there are times, when the } \\
\text { students occasionally sent posts that } \\
\text { were off topic (level 2) } \\
\text { Eg: "hmmm..if other students from } \\
\text { the other classes read our } \\
\text { classes(blog) the only word they will } \\
\text { say to us is " } P E R A S A N \text { " (self- } \\
\text { praised) (A3C) }\end{array}$ \\
\hline Blog & $\begin{array}{c}\text { Expression Within } \\
\text { the Post }\end{array}$ & $\begin{array}{l}\text { Expresses opinions and ideas in a } \\
\text { clear and concise manner with } \\
\text { obvious connection to topic. } \\
\text { Most of the time, the students will } \\
\text { relate to the topic: } \\
\text { "Scary...I will not read this, please } \\
\text { write about another story." (A3D) } \\
\text { "I feel scary too when I read the story } \\
\text { but, the English is simple, easy to } \\
\text { understand." (A3A) } \\
\text { "Interesting, full of suspense, you } \\
\text { keep asking yourself questions while } \\
\text { you are reading." (A3B) }\end{array}$ & $\begin{array}{l}\begin{array}{c}\text { Opinions and ideas are stately } \\
\text { clearly with occasional lack of } \\
\text { connection to topic. }\end{array} \\
\text { "You give me a call just to tell me } \\
\text { this?" (A2C) } \\
\text { "We are online now, oh my dear, this } \\
\text { is Chinese New Year holiday, we } \\
\text { cannot work, triple pay, man;)" } \\
\text { (A2A) } \\
\text { "At least we start posting in our } \\
\text { blog." (A2D) } \\
\text { The students still talk about their blog } \\
\text { but the posts were irrelevant to the } \\
\text { topic they earlier discussed. }\end{array}$ \\
\hline & $\begin{array}{l}\text { Contribution to the } \\
\text { Learning } \\
\text { Community }\end{array}$ & $\begin{array}{l}\text { Frequently attempts to direct } \\
\text { the discussion and to present } \\
\text { relevant viewpoints for } \\
\text { consideration by group; interacts } \\
\text { freely }\end{array}$ & $\begin{array}{l}\text { Frequently attempts to direct } \\
\text { the discussion and to present } \\
\text { relevant viewpoints for } \\
\text { consideration by group; interacts } \\
\text { freely }\end{array}$ \\
\hline
\end{tabular}

Posts: Fleming's Online Assessment Tool (Face-to face and Virtual Supervisions

The finding shows that the students' posts fell in the same categories both during face-to-face and virtual supervision. This reflects the fact that the students were not affected by the presence of the teacher. They still posted in their blogs consistently by responding their friends' posts in less than 24 hours and they also demonstrated good self-initiative in their blog discussion. All students also consistently used grammatically correct posts with rare misspellings. In fact, when they were interviewed, they admitted that they checked their work first before posting in their blogs. During both supervisions, they frequently posts topics that are related to discussion content prompts further discussion of topic. They prompted each other to make sure everybody managed to contribute in their discussion. The students also expressed their opinions and ideas in a clear and concise manner with obvious connection to topic and frequently 
attempts to direct the discussion and to present relevant viewpoints for consideration by group and they also interacted freely.

Their blog posts showed they contributed more during the virtual supervision than the face-to-face supervision except for group Alpha 2. The students did give different reactions when they were asked about their feelings to post in their blogs while their teacher was monitoring them. They felt more comfortable when they were virtually supervised. The presence of a teacher in a way did create some uncomfortable feeling among the students as some students responded:

\begin{tabular}{|l|l|}
\hline A5A & $\begin{array}{l}\text { "Teacher, you were there. I felt the tense because I know you are } \\
\text { watching us." }\end{array}$ \\
\hline A5C & $\begin{array}{l}\text { "It is as if you are looking for our errors, we need to behave } \\
\text { ourselves. We want to discuss, but I know you will not want us to } \\
\text { use Bahasa Melayu, and we want to post in our blog, but it was } \\
\text { like we don't have the confident when you are looking at us." }\end{array}$ \\
\hline A2D & $\begin{array}{l}\text { "I feel more freedom to blog from my own place. Nobody is } \\
\text { looking at me and nobody knows whether I keep referring to } \\
\text { dictionary or Google check my sentences first before I post } \\
\text { them." }\end{array}$ \\
\hline A2A & $\begin{array}{l}\text { "My group members help me more when teacher is not around. I } \\
\text { prefer blogging at home." }\end{array}$ \\
\hline
\end{tabular}

Both groups, Alpha 5 and Alpha 2 were boys groups. The other 3 groups; Alpha 1, 3 and 4 which were girls groups gave positive responses to both types of supervisions.

\section{Discussion}

This study investigated students' perception towards the use of blogs in their teaching and learning of second language specifically for extensive reading and examined the effects of the presence of teacher on students' blog posts.

15 out of $20(75 \%)$ students described that by using blogs as a platform for them to collaborate they had more courage to use the language since they had more time to construct sentences before posting them in their group blogs. They were not working under time pressure. 16 out of $20(80 \%)$ students reported that they were more willing to share their reading experience with others in blogs rather than during face-to-face in-class discussion because they felt that their blog group mates supported them during the discussion. This is consistent with the findings of Jarrell and Freiremuth (2005) and Hammond (2000) studies, which revealed that students preferred online chat rather than face-to-face in-class discussion because they felt more relaxed and they had time to think and write it down. Yang (2009) also found out that by using blogs, students had developed communication skills and Churchill (2009) also found out that 80\% students felt themselves as important part of their class when using blogs because everybody had equal opportunities to contribute to the discussion. This is also consistent with the findings of Park, Heo, and Lee's study (2011), which revealed that adult learners considered blogging as self-directed and they were aware of the personal learning benefits blogging provided, but not clear on the learning community perspective of blogging.

All students, regardless gender and linguistic competencies agreed that blogs could improve their language performance of because they have more opportunities to use the language, not merely in their language class and they became more independent in choosing their own reading materials to be shared with their group members. This finding agrees with the findings from the studies carried out by Biesbench-Lucas (2003) that asynchronous nature of e-learning allows students to read and think about the message received from group members without the pressure of immediate response and Ziman (2002) who found out that online ClassForum provides another place for students to participate after class. Yang also (2009) reported that the use of blogs for discussion was more effective than face-to-face discussion. Coutinho (2007) and Zeng and Harris (2005) obtained similar results

The present study also examined the effect of the presence of a teacher on students' participation in blogs. Although their blog posts showed the equal quality of posts and responses for both types of supervision, the students' responses during the interview indicated that boys felt more at ease during virtual supervision compared to during face-to-face supervision. The other studies also found out that students felt freer to participate in online discussion because of the absence of teachers from the discussion (Hammond, 2000) and the learning process became more student-centered (Ziman, 2002).

One limitation of the present study is the sample size. Only one class consisted of 20 students involved in this study. Future and further research should be conducted in a larger context with many classes and more participants. Another limitation is only one teacher involved directly in this study and another teacher to assist in the coding. By having more teachers, different views from the teachers' perspective about BALL can be gathered. The future study should also carry out this programme for a longer duration so that students feel more comfortable using blogs and also to generate more data from the students' experience.

Based on the discussion with the students, the researcher has come out with several ways to solve the problems faced by the students along the programme to make sure the implementation of BALL give the optimum impact to students:

- The school administration agreed to provide the computer lab with the wireless wi-fi detector which enabled us to connect to the main wi-fi from the school office. This made the internet connection become faster.

- to solve the problems of reluctant group members, the teacher highlighted to the students the importance of blogging which would help them to improve their English tremendously. The teacher 
also informed the students that their participation in blogging would be counted and evaluated and their group performance was based on all group members' participation.

- the students said they did not give the feedback immediately because they did not know when their group members posted in the blogs. The members agreed to send messages via mobile phones to their group members once they posted in their blogs as a notification to others.

- the teacher encouraged the students to use L2 as much as possible during face-to-face discussion instead of using Kelantanese dialect. The students said blogs provided a platform for them to use L2 and they preferred to use their mother tongue during face-to-face discussion but they would try to apply as much English as possible in their discussion.

- the teacher highlighted the purpose of blogging in which they were supposed to share information, not to criticize each other. The team leaders for each group shouldered the responsibility to monitor the group members' posts and comments. The teacher also provides the guidelines for the students to follow in posting their entries and comments in blog.

- the teacher provided a guideline for the students of the dos and the donts when they post their entries and comments in their blogs.

\section{Conclusion}

The use of BALL can help to boost students' use of L2, but teachers need to remember not to ignore the students who are too conscious about their linguistic competency and about what they would say about them. The findings from the study carried out by Holmes (2000) on intercultural communication of Chinese students show that students have ideas but they do not have enough time. The data gathered from the present study indicates that some students were too conscious of their language use and kept restructuring their sentences before they managed to post in their blogs. Teachers need to identify these students and keep encouraging them to explore the language, use the language as they will be able to learn and improve in the targeted language by making practicing the language.

Students believed that the use of blogs could impact their learning and participation both inside and outside the classroom. The use of blogs allows them to spend more time dealing with activities using L2. Teachers also need to know their roles when practicing BALL because if they interfere too much in the process, students might not feel comfortable. The question now is, are English teachers ready to inculcate BALL in their teaching and learning process to help students to use the language as much as possible outside their language class?

\section{References}

Alexander, B. (2006). Web 2.0: A new wave of innovation for teaching and learning? Educause , Review, 41(2), $32-44$. Retrieved on December 30, 2011 from http://www.educause.edu/ir/library/pdf/erm0621.pdf.

Arani, A. J. (2005). Teaching reading and writing English through a web-based communicative medium: Weblog. ESP WORLD, 3(4). Retrieved 16 January, 2009, from

http://www.espworld.info/Articles_11/TeachingReadingandwritinginESPthroughaWebBasedCommunicativeMedium.h m Aycock, A., Garnham, C., \& Kaleta, R. (March 20, 2002). Lessons learned from the hybrid course project. Teaching with Technology Today, 8(6), 1-6.

Biesenbach-Lucas, S. (2003). Asynchronous discussion groups in teacher training classes: Perceptions of native and non-native students[Electronic version]. Journal of Asynchronous Learning Network, 7(3),(24-46).

Cheng, M. C. (2006, March). Integrating the Internet into English composition class: Blogs, instant messaging, and email. Paper presented at 2006 International Conference and Workshop on TEFL and Applied Linguistics, Department of Applied English, Ming Chuan University, Taipei, Taiwan.

Chiao, T. L. (2006, July). Application of blogging in EFL writing class: A case study. Paper presented at the Fifth International Symposium on English teaching, Taipei, Taiwan.

Churchill, D. (2009). Educational applications of Web 2.0: Using blogs to support teaching and Learning. British Journal of Educational Technology, 40(1), 179-183.

Creswell, J. W. (2013). Qualitative inquiry and research design: Choosing among five approaches. Los Angeles: Sage. Coutinho, C. P. (2007). Cooperative learning in higher education using weblogs: A study with undergraduate students of education in Portugal. Proceedings of the 5th International Conference on Education and Information Systems, Technologies and Applications (EISTA) (pp. 60-64). Orlando: EUA. Julho.

Ellison, N., \& Wu, Y. (2008). Blogging in the Classroom: A Preliminary exploration of student attitudes and impact on comprehension. Journal of Educational Multimedia and Hypermedia, 17(1), 99-122.

Farmer, B., Yue, A. \& Brooks, C. (2008). Using blogging for higher order learning in large cohort university teaching: A case study. Australasian Journal of Educational Technology, 24 (2), 123-136. Retrieved February 26, 2008, from http://www.ascilite.org.au/ajet/ajet24/farmer.html

Ferdig, R.E. and Trammell, K.D. (2004) 'Content delivery in the 'Blogosphere', Technological Horizons in Education Journal, February [Online]. Available at: http://thejournal.com/Articles/2004/02/01/Content-Delivery-in-theBlogosphere.aspx (Accessed: 7 February 2011).

Fleming, 2008, Using best practices in online discussion and assessment to enhance collaborative learning. College Teaching Methods \& Styles Journal, 4 (10) (2008), pp. 21-39

Good, J. M. \& Whang, P. A. (2002). Encouraging reflection in pre-service teachers through response journals. The Teacher Educator, 37(4), 254-267.

Halic, O., Lee, D., Paulus, T., \& Spence, M. (2010). To blog or not to blog: Student perceptions of blog effectiveness for learning in a college-level course. The Internet and Higher Education, 13, 206-213. 
Hurlburt, S. (2008). Defining tools for a new learning space: writing and reading class blogs. Journal of Online Learning and Teaching, 4(2). Retrieved on December 30, 2011, from http://jolt.merlot.org/vol4no2/hurlburt0608.htm Holmes, P. (2000). The intercultural communication experiences of ethnic Chinese students in a western tertiary institution: Implications for education providers. (Working Paper Series No. 14). Hamilton, New Zealand: University of Waikato, Department of Management Communication.

Jerrell, D., \& Freiermuth, M.R. (2005). The Motivational Power of Internet Chat. RELC, 36(1), 59-72

Lin, M. H., Lin, C. Y., \& Hsu, P. Y. (2011). The unrealistic claims for the effects of classroom blogging on English as a second language, students' writing performance. British Journal of Educational Technology, 42(6), E148-E151. Lin, M. H., Groom, N., \& Lin, C.-Y. (2013). Blog-Assisted Learning in the ESL Writing Classroom: A Phenomenological Analysis. Educational Technology \& Society, 16 (3), 130-139.

Miyazoe, T., \& Anderson, T. (2010). Learning outcomes and students' perceptions of online writing: Simultaneous implementation of a forum, blog, and wiki in an EFL blended learning setting. System, 38(2), 185-199.

Nelson, J., Christopher, A., \& Mims, C. (2009). TPACK and Web 2.0: Transformation of teaching and learning. TechTrends: Linking Research \& Practice to Improve Learning, 53(5), 80-87. doi:10.1007/s11528-009-0329-Z Park, Y., Heo, G. M., \& Lee, R. (2011). Blogging for Informal Learning: Analyzing Bloggers' Perceptions Using Learning Perspective. Educational Technology \& Society, 14 (2), 149-160.

Pinkman, K. (2005). Using blogs in the foreign language classroom. JALT CALL Journal , 1(1), 12-24.

Scheidt, L. A. (2009). Diary weblogs as genre (Doctoral dissertation). Retrieved on December 30, 2011 from http://citeseerx.ist.psu.edu/viewdoc/download?doi=10.1.1.154.3724 \&rep=rep1\&type=pdf

Sun, Y. C. (2010). Extensive writing in foreign-language classrooms: A blogging approach. Innovations in Education and Teaching International, 47(3), 327-339.

Ward, J. M. (2004). Blog assisted language learning (BALL): Push button publishing for the pupils. TEFL Web Journal, 3(1). Retrieved October 25, 2008 from http://www.teflWeb-j.org/v3n1/blog_ward.pdf

Williams, J. B. \& Jacobs, J. (2004). Exploring the use of blogs as learning spaces in the higher education sector. Australasian Journal of Educational Technology, 20(2), 232-247.

Wu, W. S. (2008). Using blogs in an EFL writing class. In Priya, S. (Ed.), Netlingo: The metamorphosis of language (pp. 86-99). Hyderabad, India: The Icfai University Press.

Xie, Y., Ke, F., \& Sharma, P. (2007). The effect of peer feedback for blogging on college students' reflective learning processes. The Internet and Higher Education, 11(4), 18-25.

Xie, Y., Ke. F. \& Sharma, P. (2010). The effect of peer-interaction styles in team blogging on students' cognitive thinking and blog participation. Journal of Educational Computing Research. 42(4), 459-479.

Yang, C. \& Chang, Y. S. (2012). Assessing the effects of interactive blogging on student attitudes toward peer interaction, learning motivation, and academic achievements. Journal of Computer Assisted Learning, 28(2), 126-135. Yang, S.-H. (2009). Using blogs to enhance critical reflection and community of practice. Educational Technology \& Society, 12(2), 11-21.

Yena, L., \& Waggoner, Z. (2003). One size fits all?: Student perspectives on face-to-face and online writing pedagogies. Computers \& Composition Online. Retrieved June 13, 2009, from http://www.bgsu.edu/cconline/yenawaggo/

Zeng, X. \& Harris, S. T. (2005). Blogging in an online health information technology class. Perspectives in Health Information Management. 2:6. Retrieved on February 26, 2012 from

http://www.ncbi.nlm.nih.gov/pmc/articles/PMC2047310/.

Ziman, M. (2002). On-line activities enhance student-centred learning. In A. Goody, J. Herrington \& M. Northcote (Eds.), Proceedings of the 2002 Annual International Conference of the Higher Education Research and Development Society of Australasia (HERDSA), Perth, Australia. [Online conference proceedings]. Available:http://www.herdsa.org.au/publications/ 